\title{
Exiles and the Politics of Reintegration in the Dutch Revolt
}

Janssen, G.H.

\section{Citation}

Janssen, G. H. (2009). Exiles and the Politics of Reintegration in the Dutch Revolt. History. Journal Of The Historical Association, 94, 36-52. Retrieved from https://hdl.handle.net/1887/14992

Version:

Not Applicable (or Unknown)

License:

Leiden University Non-exclusive license

Downloaded from: $\quad$ https://hdl.handle.net/1887/14992

Note: To cite this publication please use the final published version (if applicable). 


\title{
Exiles and the Politics of Reintegration in the Dutch Revolt
}

\author{
GEERT H. JANSSEN \\ University of Cambridge
}

\begin{abstract}
The civil war in the sixteenth-century Low Countries, generally known as the Dutch revolt, generated dramatic streams of refugees. Whereas scholars in the past have devoted much attention to the exile experience of Protestants in particular, the circumstances surrounding the return of these refugees to the Netherlands have remained largely unexplored. This article focuses on the repatriation and reintegration of Protestant exiles in the province of Holland in the years 1572-80. It seeks to assess what strategies returning exiles developed to regain their possessions and respectability in local communities and shows how they adopted rituals of cleansing to reinforce their social rehabilitation. It can be demonstrated that the exiles consciously used the houses and properties of their Catholic enemies to mark their re-entry in Holland society. By appropriating possessions of escaped Catholic citizens, the former 'victims' of the Habsburg regime sought material compensation and styled themselves as members of a new civic elite. In this way two contrasting streams of refugees became symbolically connected because it was fugitive Catholics who provided returning Protestants with the tools to turn themselves from outlaws into the icons of the nascent Dutch Republic.
\end{abstract}

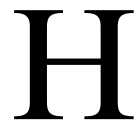

ow could a criminal conviction be an asset for public office in early modern Holland? The citizens of Amsterdam must have pondered this question when in 1578 their local city council was renewed and more than fifteen sentenced individuals were appointed to the new body. ${ }^{1}$ As former outlaws the men had much in common. They had all previously been banished by the Habsburg government and most of them had spent their exile in the German town of Emden. The outbreak of the Dutch revolt, however, had resulted in a change in the exiles' fortunes. As soon as Amsterdam switched to the side of the rebels, the exiles returned in large numbers, as happened in many Holland towns which joined the rebellion after 1572 . From being outcasts and personae

The research for this article was generously supported by the Netherlands Organization for Scientific Research (NWO). I am grateful to audiences in Amsterdam and Cambridge, as well as to Alastair Duke, Andrew Spicer and James Tracy for their comments on earlier versions of this article.

1 J. Elias, De vroedschap van Amsterdam (2 vols., Haarlem, 1903-5). 
non gratae, the returning refugees quickly transformed themselves into the icons of the new rebel regime, and ultimately into the self-proclaimed founding fathers of the nascent Dutch Republic.

The paradoxical tale of the Protestant exiles in the Dutch revolt is not unknown to historians, yet their shifting experiences have only received partial study. A good deal of research has been carried out in recent decades into the refugee movement from the Habsburg Low Countries on the eve of the revolt. This historiography has generally focused on the magnitude of these migrations in the $1540 \mathrm{~s}$, 1550s and $1560 \mathrm{~s}$, on the subsequent development of Reformed exile churches abroad, and on the role played by these refugee communities in local economies in England and the Holy Roman Empire. ${ }^{2}$ It was generally supposed that most exiles had tried to return after 1572 once the Dutch revolt seemed to be successful. Indeed, in the following years a wave of remigration became conspicuous in rebel-controlled areas.

While scholars have devoted much attention to the exiles' residence abroad, the circumstances surrounding their return have remained largely unexplored. ${ }^{3}$ Historians of the early modern Netherlands have traditionally stressed the formative role of returning exiles in the emerging Reformed churches and have pointed to their political and military agency in the revolt. ${ }^{4}$ Yet none of these studies provides an idea of the practical consequences of this process of remigration, of the possible tensions that came with the reintegration of exiles in local communities, let alone of the way in which these former outlaws articulated and negotiated their newly adopted role in society. How, for example, did those who had been criminalized by the Habsburg government actually mark their re-entry in the towns which they had been forced to leave several years earlier? And how did local citizens respond to their

\footnotetext{
2 See for example M. Backhouse, The Flemish and Walloon Communities at Sandwich during the Reign of Elizabeth I 1561-1603 (Brussels, 1995) [hereafter Backhouse, Flemish and Walloon Communities]; A. Dünnwald, Konfessionsstreit und Verfassungskonflikt. Die Aufnahme der niederländischen Flüchtlinge im Herzogtum Kleve 1566-1585 (Bielefeld, 1998); Raingard Esser, Niederländische Exulanten im England des 16. und frühen 17. Jahrhunderts (Berlin, 1996) [hereafter Esser, Niederländische Exulanten]; Ole Grell, Calvinist Exiles in Tudor and Stuart England (Aldershot, 1996) [hereafter Grell, Calvinist Exiles]; Andrew Pettegree, Foreign Protestant Communities in Sixteenth-Century London (Oxford, 1986) [hereafter Pettegree, Foreign Protestant Communities]; Andrew Pettegree, Emden and the Dutch Revolt: Exile and the Development of Reformed Protestantism (Oxford, 1992) [Pettegree, Emden]; Heinz Schilling, Niederländische Exulanten im 16. Jahrhundert: Ihre Stellung im Sozialgefüge und im religiösen Leben deutscher und englischer Städte (Gütersloh, 1972) [hereafter Schilling, Niederländische Exulanten]; Andrew Spicer, The French-speaking Reformed Community and their Church in Southampton, 1567-c.1620 (Stroud, 1997) [hereafter Spicer, French-speaking Reformed Community].

3 Compare Gustaaf Janssens, 'Verjaagd uit Nederland. Zuid-Nederlandse emigratie in de zestiende eeuw, een historiografisch overzicht (ca.1968-1994)', Nederlands archief voor kerkgeschiedenis, lxxv (1995), 102-19.

${ }^{4}$ General overviews are offered in J. I. Israel, The Dutch Republic: Its Rise, Greatness and Fall, 1477-1806 (Oxford, 1998) [hereafter Israel, Dutch Republic], pp. 158-60; A. C. Duke, Reformation and Revolt in the Low Countries (1990) [hereafter Duke, Reformation and Revolt], pp. 199-226; Andrew Pettegree, 'Coming to Terms with Victory: The Upbuilding of a Calvinist Church in Holland, 1572-1590', Calvinism in Europe 1540-1620, ed. A. Duke et al. (Cambridge, 1996), pp. 160-80.
} 
unforeseen return? The property and homes of the outlaws had generally been confiscated during their absence and even the physical memory of their existence had often been erased by the authorities. What strategies did the returning exiles develop to regain their possessions and respectability and how did they express their changing status in a community challenged by the experience of civil war?

Such questions are relevant, not only because patterns of reintegration in early modern society have received little study so far, but also because the case of the Dutch Protestants may shed important light on the nature of the conflict in the Low Countries. In recent years, historians have become increasingly aware that the Dutch revolt may best be approached in terms of a civil war, yet the broader implications of that shifting view still await further assessment. ${ }^{5}$ The perspective of refugee movements may be a rewarding starting-point in this respect as they can illuminate internal divisions in Netherlands society. More specifically, this article seeks to assess the rituals of cleansing which returning exiles used in order to rehabilitate themselves in local communities, and identify the models and traditions on which these were based. In so doing, it will be argued that the reintegration of Protestant outlaws was intrinsically connected to the simultaneous flight of loyalist, Catholic citizens whose houses and physical possessions were appropriated, purged and used as an instrument of rebel propaganda. Two contrasting streams of refugees thus became symbolically connected, as it was loyalist Catholics who provided exiled Protestants with the tools to turn themselves from outcasts into the protagonists of a new regime. To show precisely how this process worked, this article will concentrate on the reintegration of Protestant exiles in the Holland towns in the crucial early years of the conflict: $1572-80$.

\section{I}

The Protestant exodus from the Low Countries had largely been the result of Habsburg confessional policies. From the 1540s onwards, small groups of evangelical believers started to escape the Catholic Habsburg Netherlands and settled in Protestant safe havens abroad. After the uprisings of 1566 and subsequent rumours about the arrival of Spanish troops under the leadership of the duke of Alva, a vast and more mixed stream of religious, political and economic migrants left the provinces of the Netherlands, including Holland. ${ }^{6}$ The destinations of these various

\footnotetext{
5 Peter Arnade and Henk van Nierop, 'The Political Culture of the Dutch Revolt', Journal of Early Modern History xi (2007) [hereafter Arnade, Van Nierop, 'The Political Culture'], 253-61; Compare Reformation, Revolt and Civil War in France and the Netherlands 1555-1585, ed. Philip Benedict et al. (Amsterdam, 1999); The Origins and Development of the Dutch Revolt, ed. G. Darby (2001); Anton van der Lem, De opstand in de Nederlanden, 1555-1609 (Utrecht, 1995).

${ }^{6}$ It is estimated that in $1566-7$ between 30,000 and 60,000 people left the Low Countries. See Israel, Dutch Republic, p. 160.
} 
groups of refugees differed, yet large concentrations of Netherlandish migrants were soon to be found in refugee centres such as Emden and Wesel in the Holy Roman Empire and London and Norwich in England. ${ }^{7}$

Going into exile was a decision with dramatic consequences not least because of the draconian responses of the Habsburg government at home. When the duke of Alva actually arrived in the Low Countries, in the autumn of 1567, he installed a 'Council of Troubles', which was set to prosecute those responsible for the disturbances of the previous year. Among its victims were several hundred exiles. Most of them were sentenced to death in absentia, or to eternal banishment with the confiscation of their goods. ${ }^{8}$ Alva's measures thus turned 'voluntary' refugees, who may have hoped to repatriate at some point, into criminals and permanent personae non gratae.

A number of historians have shown how the experience of displacement and the loss of possessions forced many Netherlanders abroad to redefine their position in society. Alastair Duke in particular has pointed out that the exile experience created a sense of mutual solidarity among the diverse Netherlandish communities abroad and encouraged the development of a common 'Hispanophobic' agenda. In this way, repressive Habsburg policies seem to have triggered the emergence of some sort of 'national' identity in exile circles. ${ }^{9}$ This process was simultaneously shaped by the activism of the refugee churches. There is ample evidence that these Reformed congregations played a vital role in accommodating exiles, and also provided them with a new, more militant confessional programme. It was in places such as Emden and London that many with eclectic evangelical views gradually transformed into fixed Calvinists. As Andrew Pettegree has demonstrated, the experience of flight and displacement fostered a new religious mentality among exiles, which converted their passive victimhood into confessional militancy. ${ }^{10}$

The exiles' radicalization, a paradoxical by-product of Alva's policies, also made the émigré community receptive to the propaganda vocabulary of William of Orange (1533-84), himself an exile. Orange had escaped

\footnotetext{
7 For England see Esser, Niederländische Exulanten; Backhouse, Flemish and Walloon Communities; Pettegree, Foreign Protestant Communities; Spicer, French-speaking Reformed Community. For the Holy Roman Empire see R. van Roosbroeck, Emigranten: Nederlandse vluchtelingen in Duitsland (1550-1600) (Leuven, 1968); Schilling, Niederländische Exulanten; Pettegree, Emden.

${ }^{8}$ Overviews of sentences are collected in Le conseil des troubles: Liste des condamnés (1567-1573), ed. A. L. E. Verheyden (Brussels, 1961) [hereafter Verheyden, Le conseil]. Specific for Holland is Sententiën en indagingen van den hertog van Alba, ed. J. Marcus (Amsterdam, 1735) [hereafter Marcus, Sententiën]. Alva's punishment policy was in line with his royal instructions. See Violet Soen, 'C'estoit comme songe et mocquerie de parler de pardon. Obstructie bij een pacificatiemaatregel (15661567)', Bijdragen en mededelingen betreffende de geschiedenis der Nederlanden cxix (2004), 309-28.

9 Duke, Reformation and Revolt, pp. 186-8, as well as: Alastair C. Duke, 'The Elusive Netherlands: The Question of National Identity in the Early Modern Low Countries on the Eve of the Revolt', Bijdragen en mededelingen betreffende de geschiedenis der Nederlanden, cxix (2004), 36.

10 Pettegree, Emden, pp. 237, 245; also Grell, Calvinist Exiles, p. 113. Compare Jonathan Wright, 'Marian Exiles and the Legitimacy of Flight from Persecution', Journal of Ecclesiastical History, lii (2001), 220-43.
} 
the Low Countries in 1567 and was among the most prominent convicts of the Council of Troubles. After his possessions had been confiscated and his eldest son had been brought to Spain, Orange started a military campaign against Alva. Exiles played an important part in Orange's plans, even though the relationships between the Calvinist refugee churches and the prince were not uncomplicated. ${ }^{11}$ Hollanders in particular seem to have occupied a key position in the prince's network of agents and fundraisers. ${ }^{12}$

\section{II}

After several failed attempts, Orange undertook a new military invasion in 1572. Although the campaign had been carefully planned, the way in which the rebellion developed was quite different from the prince's intentions. ${ }^{13}$ After the unexpected capture of Den Briel by a fleet of exile privateers, the so-called 'Sea Beggars', the Holland towns were swiftly forced to choose sides. Whereas historians have found it difficult to discern a pattern in the varied responses of the towns, there is little doubt about the instrumental role of exiles in the process. ${ }^{14}$ Various sources confirm that during the months of chaos and emerging civil war, exiles secretly returned and - in some cases on the instruction of Orange started to manipulate local public opinion. Many of these agents still had family networks to rely on and were able to adjust the prince's demands to local circumstances. ${ }^{15}$

The Habsburg government soon identified the role played by exiles in destabilizing the political status quo. The secretary to the Secret Council

11 Compare the correspondence in Archives ou correspondance inédite de la Maison d'Orange-Nassau Supplément au recueil de M. G. Groen van Prinsterer: La Correspondance du prince avec Jacques de Wesenbeke, ed. J. F. van Someren (Utrecht, 1896); Ecclesiae Londino-Batavae Archivum, ed. J. H. Hessels (4 vols., Cambridge 1887-97) [hereafter Hessels, Ecclesiae], ii. 418; A. Kluit, Historie der Hollandsche staatsregering to aan het jaar 1795 (Amsterdam, 1802) [hereafter Kluit, Historie], pp. 488-91. The émigré community had long been divided about supporting a rebellion. O. Boersma, Vluchtig voorbeeld: De Nederlandse, Franse en Italiaanse vluchtelingenkerken in Londen 1568-1585 (The Hague, 1994), pp. 188-93.

12 Names can be found in Kluit, Historie, pp. 493-508.

13 For a chronology of events see Geoffrey Parker, The Dutch Revolt (reprint, 1985) [hereafter Parker, Dutch Revolt]. A compelling case study is offered by Henk van Nierop, Het verraad van het Noorderkwartier. Oorlog, terreur en recht in de Nederlandse Opstand (Amsterdam, 1998) [hereafter Van Nierop, Het verraad].

14 J. C. Boogman, 'De overgang van Gouda, Dordrecht, Leiden en Delft in de zomer van het jaar 1572', Tijdschrift voor Geschiedenis, lvii (1942) [hereafter Boogman, 'De overgang'], 81-112; Henk van Nierop, Het foute Amsterdam (Amsterdam, 2000) [hereafter Van Nierop, Het foute Amsterdam], pp. $10-13$.

15 As becomes apparent from surviving commission letters in Correspondentie Willem van Oranje, ed. J. Smit (The Hague, 2005), available at http://www.inghist.nl/Onderzoek/Projecten/WVO [hereafter Correspondentie Willem van Oranje], 10577, 10304, 11170. Other examples in Kluit, Historie, pp. 51219; Pieter Christiaensz Bor, Oorsprongk, begin, en vervolgh der Nederlandsche oorlogen, beroerten, en borgerlyke oneenigheden (4 vols., Amsterdam 1679-84) [hereafter Bor, Oorsprongk], i. 371-7; Marcus, Sententiën, pp. 241-6; Van Nierop, Het verraad, pp. 72-81; J. C. A. de Mey, De watergeuzen en de Nederlandse opstand (Amsterdam, 1972) [hereafter De Mey, De watergeuzen], pp. 92-8. 
in Brussels, Viglius van Aytta, pointed to the dangerous propaganda messages, spread by those 'qui hinc banniti fuerunt' ['who have been banished from this place'], while the king's stadholder in Holland, Maximilian of Boussu, warned Alva on 24 May that 'aulcuns bannis se commencent à monstrer sur les rues' ['some exiles are starting to appear in the streets'] ${ }^{16}$ More concrete measures against their alarming activities were taken during the spring. On 8 May 1572 a provincial decree was published in Holland in which any personal contact with 'wandering rebels' and returning 'fugitives' was strictly forbidden - on penalty of death. ${ }^{17}$ At the same time, the coastal patrol near The Hague was intensified since it was rumoured that ships with exiles and troops were on the way from Emden and London. These stories were confirmed by an ordinance of 9 June in which the magistrates of The Hague warned about an increasing number of 'strangers' and 'exiles' in the area. From now on, all landlords in town had to provide the officials with daily lists of their guests. ${ }^{18}$ These and similar efforts to frustrate the mobility of outlaws were not unsuccessful. As early as May it was reported that some of them had been captured and were brought into custody in The Hague. In Rotterdam too, several exiles suffered in gaol after being arrested in the seaports Delfshaven and Katwijk. ${ }^{19}$

Yet most indicative for their vital role was the response of the towns that resisted rebel pressure, notably Amsterdam. As a result of political tensions and religious unrest in the years before 1566, the biggest town of Holland had spawned a relatively large exile community. It was obvious to the local authorities that the activities of these outlaws and their families offered a continuous threat to the stability in the town. Thus, from spring 1572 onwards, the Amsterdam magistrates issued a number of ordinances that strictly regulated in- and outgoing traffic in the city. During the following years the authorities managed to prevent the return of former citizens or the entry of agents of Orange. When Alva's successor, Don Luis de Requesens, ordered a general pardon in 1574, Amsterdam pleaded successfully for excluding any exiles. ${ }^{20}$ So long as returning exiles

16 Quoted in Boogman, 'De overgang', 112. See also J. van Vloten, Nederlands opstand tegen Spanje, in zijn eerste wording en voortgang (1572-1575) (Haarlem, 1858) [hereafter Van Vloten, Nederlands opstand], p. lxiii; Parker, Dutch Revolt, pp. 126-38.

17 J. Smit, 'De omzetting van het Hof van Holland in 1572', Bijdragen voor de vaderlandsche geschiedenis en oudheidkunde (1925) [hereafter Smit, 'De omzetting'], 184; Van Vloten, Nederlands opstand, p. xviii.

18 Nationaal archief, The Hague [hereafter NA], Grafelijkheidsrekenkamer, 683b, J. van Valckesteijn to Willem Schouten, The Hague 19 May 1572. Compare J. Smit, Den Haag in den Geuzentijd (The Hague, 1922) [hereafter Smit, Den Haag], pp. 163-4.

19 For The Hague, see Smit, 'De omzetting', p. 184; Smit, Den Haag, pp. 163-5; For Rotterdam see H. ten Boom, De reformatie in Rotterdam, 1530-1585 (The Hague, 1987) [hereafter Ten Boom, De reformatie], p. 137.

20 Van Nierop, Het foute Amsterdam, pp. 14-15; Van Nierop, Het verraad, p. 196; Pettegree, Emden, p. 159. Compare Dagboek van broeder Wouter Jacobsz, ed. I. H. van Eeghen (2 vols., Groningen, 1959-60) [hereafter Van Eeghen, Dagboek], i. 421. 
were unable to express their views, the government in power seemed able to control public opinion.

The precautionary measures of the Amsterdam magistrates do not just point to the threat offered by exiles but also to the growing stream of repatriates in the course of 1572. Although it is not possible to calculate their number precisely, a few surviving sources provide a general impression. Intelligence from Maximilian of Boussu notes that within a week of the seizure of Den Briel two ships with 150 men embarked from Emden, followed by another group of 300 the following week. ${ }^{21}$ In May groups of exiles from London, Ipswich, Norwich and Colchester set foot in Holland. In a letter dated 28 April Maximilian Morillon in Brussels informed Cardinal Granvelle about a general repatriation of exiles from England and Germany who allegedly came to assist the rebellion. ${ }^{22}$ Indeed, in the course of 1572 the Netherlands communities abroad received repeated requests from the rebel towns to send over members of their congregation as well as money and troops. ${ }^{23}$ A thousand soldiers set sail from Emden to Holland on 24 June, while Lazarus Muller arrived together with 600 harquebusiers from Bremen in August. ${ }^{24}$

The large numbers of repatriates suggests that the Netherlandish community abroad enthusiastically joined the rebellion of $1572-$ an assumption that was cultivated in the older historiography. In fact, the response to the revolt was more varied and ambiguous. For exiles from the provinces of Brabant and Flanders, a (temporary) settlement in Holland was not exactly what they had been hoping for. What is more, the émigré community partly consisted of merchants who had fled for economic rather than religious reasons. Not directly affected by Alva's measures, these entrepreneurs did not want to be involved in a bloody civil war. Several Emden and London merchants were even engaged in a lucrative trade with representatives of the Habsburg regime. ${ }^{25}$ In the following years William of Orange typically made every effort to encourage reluctant entrepreneurs in Bremen, Hamburg and London to return and reactivate the economy in the rebel-controlled areas. ${ }^{26}$ Their passive stand even forced the prince - in his capacity of stadholder of Holland - in March 1574 formally to order those who still remained at Emden to settle in Holland. No less than 3,300 'exiles' were reported to

\footnotetext{
21 According to intelligence sent to stadholder Boussu: Van Vloten, Nederlands opstand, p. 334; Pettegree, Emden, p. 190.

22 Taken from Pettegree, Emden, p. 190. Further references in Van Vloten, Nederlands Opstand, p. xxii; Hessels, Ecclesiae, ii. 397, 403, 406, iii. 168; Das Buch Weinsberg, ed. Konstantin Höhlbaum et al. (5 vols., Leipzig, Bonn, 1887-1926), ii. 229.

23 This request in Hessels, Ecclesiae, iii. 164, 438. Also Bor, Oorsprongk, i. 367; Spicer, Frenchspeaking Reformed Community, pp. 130-4.

24 Van Vloten, Nederlands opstand, pp. lxxx-lxxxi, lxxvi; Pettegree, Emden, pp. 190-1; Smit, 'De omzetting', 189.

25 B. Hagedorn, Ostfrieslands Handel und Schiffahrt im 16. Jahrhundert (Berlin, 1910) [hereafter Hagedorn, Ostfrieslands Handel].

${ }_{26}$ Correspondentie Willem van Oranje, 2874, 3196.
} 
have left East Friesland the same year. ${ }^{27}$ The Augustinian prior Wouter Jacobsz, who himself had taken refuge in royalist Amsterdam, confirmed in his diary on 21 May 1574 that forty ships from Emden were said to have arrived at Enkhuizen. ${ }^{28}$

However seminal the agency of exiles in the early stages of the revolt may have been, these activities reveal little about their reception in the Holland towns, and still less about the strategies used to regain - or establish - their positions in local communities. Whereas scholars in the past simply assumed that the exiles had been greeted with enthusiasm, scattered evidence suggests that the outlaws met with a more varied reaction. It was not just local authorities, but also common citizens who sometimes frustrated their return. Pieter van der Werf, a Leiden exile who arrived in Holland in spring 1572, admitted that he encountered quite a few people who were of 'different minds'. Several tavern owners in Delft deliberately refused to provide him with accommodation. ${ }^{29}$ Similar resistance to the exiles' return could be observed in the area of The Hague. Here, returning exiles allegedly threatened to burn down the houses of the local farmers to deter them from informing the government about their arrival. ${ }^{30}$ Because of the chaos of civil war and the possible purges of archives in the following decades, there is not sufficient information to allow a comprehensive reconstruction of these tensions and divisions within the Holland population. Yet a number of contemporary sources from the rebel administration shed some revealing light on the problems that exiles faced, the strategies which they developed in response and the models upon which these were based.

\section{III}

For the returning exiles, the revolt against the Habsburg government was more than just a collective religious struggle. The rebellion also served as a private war against a regime that had stripped them of their houses, belongings and reputation. This widespread resentment and the exiles' search for compensation were reflected in the improvised programme that William of Orange had formulated in 1570. The sixth article listed that "those who . . . may have departed or been banished from the town, shall be allowed to return. They shall be restored to all their property, legal documents and rights, even though these may have been seized, confiscated and alienated to another party. ${ }^{31}$ Indeed, as early as July 1572 Orange had persuaded the States of Holland to quash all condemnations

\footnotetext{
27 Hagedorn, Ostfrieslands Handel, p. 335.

28 Van Eeghen, Dagboek, i. 406.

29 His accounts in Gemeentearchief Leiden [hereafter GAL], Stadsarchief I, 1380. These have partly been published in Kluit, Historie, p. 516.

30 Smit, Den Haag, p. 244.

31 Edition taken from http://dutchrevolt.leidenuniv.nl, ed. Anton van der Lem. Text provided and translated by Alastair Duke.
} 
by the Council of Troubles and relating law courts. ${ }^{32}$ The authority of the provincial States in the matter was debatable, since rescinding orders of banishment and issuing acts of pardon could be done only by the sovereign. ${ }^{33}$ Furthermore, the resolution of the States, which implied the restitution of residences and goods and the revocation of public sales and auctions, was difficult to implement in time of war. ${ }^{34}$ After being assigned to the crown, many confiscated houses had been sold or rented out to neighbours, fellow townsmen, sometimes even to family members.

It appears that Orange and the rebel government found pragmatic solutions to these problems. So long as the return of possessions turned out to be impossible, they tried to satisfy the exiles' wishes with alternative sources of compensation. A first solution was to give them public offices. Significantly, in the course of 1572 the prince started to reward returning exiles with positions in the rebel towns and the provincial administration. Those who were not native Hollanders were given offices in the military or at Orange's private court. The prince had ample opportunity to do so, since a small, yet significant part of the Holland administrative elite had left the rebel towns in previous months. Many of these Catholic, loyalist magistracies had based themselves in royalist centres such as Amsterdam or Utrecht, confident that the military tide would soon turn. The offices they left vacant enabled Orange both to strengthen his precarious position and to reward his most committed supporters. ${ }^{35}$ Although the rebel leader was careful to give his movement a broad base, and to convince the local population that the conflict concerned a common 'Dutch' struggle against a shared 'foreign' enemy, returning exiles benefited particularly from his need for reliable replacements. ${ }^{36}$ Thus the former outlaws

\footnotetext{
32 The text in Bor, Oorsprongk, i. 391.

33 Willem van Iterson, Geschiedenis der confiscatie in Nederland: Een rechtshistorische studie aan de hand van Noordnederlandse, een aantal Zuidnederlandse en andere bronnen (Utrecht, 1957) [hereafter Iterson, Geschiedenis], pp. 184-5; Corien Glaudemans, Om die wrake wille: Eigenrichting, veten en verzoening in laat-middeleeuws Holland en Zeeland (Hilversum, 2004) [hereafter Glaudemans, Om die wrake wille], pp. 281-301.

${ }^{34}$ Compare the situation in France, where returning Huguenots struggled to recover confiscated property. Penny Roberts, 'Huguenot Petitioning during the Wars of Religion', in Society and Culture in the Huguenot World, 1559-1685, ed. Andrew Spicer and Raymond A. Mentzer (Cambridge, 2002) [hereafter Roberts, 'Huguenot Petitioning], pp. 67-76.

35 In his Annales, Frans Dusseldorpius, member of a Catholic family from Leiden, pointed to the opportunities which loyalists unintentionally offered to Orange: Uittreksel uit Francisci Dusseldorpii Annales, 1566-1616, ed. R. Fruin (Utrecht, 1893) ix, 113, 131.

36 Parker, Dutch Revolt, pp. 146-7, Israel, Dutch Republic, pp. 157-9, as well as C. C. Hibben, Gouda in Revolt: Particularism and Pacifism in the Revolt of the Netherlands, 1572-1588 (Utrecht, 1983) [hereafter Hibben, Gouda], pp. 53-93; A. Lamet, 'The Vroedschap of Leiden 1550-1600: The Impact of Tradition and Change on the Governing Elite of a Dutch City', The Sixteenth Century Journal, xii (1981), 13-42; Maarten Hell, 'Jan Coenensz. Van oude geus tot Leicestriaan', Jaarboek Amstelodamum xcvii (2005), 85-127. For similar appointments of exiles in the Holland Ridderschap see H. F. K. van Nierop, The Nobility of Holland: From Knights to Regents, 1500-1650 (Cambridge, 1993) [hereafter Van Nierop, The Nobility of Holland], pp. 181-5, 193-5.
} 
became among the greatest beneficiaries of the shifting balance of power in the Holland body politic. ${ }^{37}$

At first sight, Orange's policy for compensating exiles seems not particularly unusual. For Renaissance Italy, Christine Shaw has similarly shown that political offices were often granted to pardoned exiles as a form of rehabilitation and a means of providing compensation for material losses. ${ }^{38}$ The 'Marian exiles', who returned to England after the ascension of Elizabeth in 1558, acquired important positions in the purged government as well..$^{39}$ Yet in the polarized climate of the Dutch civil war, in which the old religious and political order was challenged, the arrangements for returning exiles probably had a broader significance. This becomes clear in the events of the following months when the rebel government took possession of the properties of its enemies. On 23 August 1572, the States of Holland proclaimed that ecclesiastical properties, as well as goods left by Catholic 'fugitives', had to be registered. ${ }^{40}$ In the following months, numerous church treasures were sold on the States' behalf whereas the supervision of ecclesiastical lands was given to provincial administrators. The attitude towards possessions left by individual Catholic citizens was somewhat different. Rather than being confiscated, the houses and possessions of loyalists were 'annotated' and temporarily rented out. ${ }^{41}$

So far scholars have mainly interpreted this dramatic decision as a sign of the demise of Catholic structures in Holland and a means to finance the revolt. ${ }^{42}$ Yet the 'politics of annotation', which started within a month after the decision to revoke criminal sentences made by the Council of Troubles, also served to accommodate the reintegration of exiles, by satisfying their demands for compensation. Significantly, in some cases the registration of ecclesiastical and private properties was actually entrusted to prominent returning exiles. Adriaan van Swieten, for example, sentenced by the Council of Troubles and previously in banishment in Germany, was made provincial treasurer of 'annotated goods' in

\footnotetext{
37 The extent of political renewal differed from town to town. Exiles (especially those from other provinces than Holland) also frequently appear in lists of provincial and military officers. Compare the numerous commission letters from 1572-6 in Correspondentie Willem van Oranje.

38 Christine Shaw, The Politics of Exile in Renaissance Italy (Cambridge, 2000), pp. 203-33.

39 Andrew Pettegree, 'The Marian Exiles and the Elizabethan Settlement', in Marian Protestantism: Six Studies, ed. Andrew Pettegree (Aldershot, 1996), pp. 129-50; N. M. Sutherland, 'The Marian Exiles and the Establishment of the Elizabethan Régime', Archiv für Reformationsgeschichte, lxxviii (1987), 253-86.

40 James D. Tracy, 'Emigré and Ecclesiastical Property as the Sheet-Anchor of Holland Finance, 1572-1584', in Reformation, Revolt and Civil War in France and the Netherlands 1555-1585, ed. Philip Benedict et al. (Amsterdam, 1999) [hereafter Tracy, 'Emigré'], p. 255; P. Noordeloos, 'Fugitieve personen in Westfriesland, Edam en Monnikendam', Archief voor de geschiedenis van de katholieke kerk in Nederland, ii (1960) [hereafter Noordeloos, 'Fugitieve personen'], 73-92.

41 The distinction between ecclesiastical and secular properties was not always made in the accounts of provincial administrators. NA, Rekenkamer ter Auditie; Grafelijkheidsrekenkamer. 42 James D. Tracy, The Founding of the Dutch Republic: War, Finance, and Politics in Holland, 1572-1588 (Oxford, 2008), pp. 109-13; Van Nierop, Het verraad, pp. 195-6.
} 
April $1573 .{ }^{43}$ In Rotterdam, former Emden exile Lenert Hendricksz Say was commissioned by the States to annotate properties left by 'fugitives'. In the area of Naaldwijk, Lodewijk van den Binckhorst, who had just remigrated to Holland, was given a similar instruction. ${ }^{44}$

As a result of this policy two contrasting streams of refugees in Holland became intrinsically linked, as several properties of escaped Catholics were now assigned to repatriating Protestants. In the course of 1572 and 1573, Catholic residences in Leiden were inhabited by those convicted by the Council of Troubles, while similarly in Delft and The Hague numerous houses of loyalists were claimed by William of Orange for members of his administration and court. ${ }^{45}$ Sources do not always reveal the conditions upon which this (temporary) exchange of possessions happened. Yet in Delft, housing was explicitly granted for free to several exiles. For example, Adriaan van Swieten occupied the house of Anthony van Blockland on the Langedijk, 'at the discretion' of the Holland account chamber. ${ }^{46}$ A similar arrangement could be made for returning exiles who originated from other provinces, notably Brabant and Flanders. Philip van der Aa, originally from Mechelen, 'returned' to Holland in 1573 and successfully asked the prince to be based in a comfortable house of a loyalist 'absentee' in the Nobelstraat in The Hague. ${ }^{47}$

William of Orange made inventive use of this combination of giftgiving and retribution. Not only did he frequently confer incomes taken from ecclesiastical properties, he also distributed precious possessions of Catholic officials among members of his entourage. ${ }^{48}$ In April 1573, the prince bestowed the humanist library of Joachim Hopperus - a high official in the Brussels government - to his trustee and former exile Marnix van St Aldegonde. ${ }^{49}$ Other prominent exiles, including Otto van Egmond and Leonard Casembroot, regularly appear in the accounts of those who received grants, deriving from annotated Catholic goods. ${ }^{50}$

\section{IV}

At first sight, the transfer of Catholic residences to returning Protestant exiles may have been a temporary and purely practical solution to

\footnotetext{
43 NA, Hof van Holland, 382, Commission for Adriaan van Swieten, Delft 22 April 1573. Also compare Correspondentie Willem van Oranje, 9550.

44 For Say: NA, Rekenkamer ter Auditie, 4578, Accounts concerning annotated goods, 2 May 1573-30 April 1574; Ten Boom, De reformatie, p. 140. For Binckhorst: Van Eeghen, Dagboek, i. 363; Smit, Den Haag, pp. 228-9; Van Nierop, The Nobility of Holland, p. 189.

45 Numerous examples in NA, Rekenkamer ter Auditie, 4544, overview of annotated houses and goods at Delft, 1573-4.

46 NA, Rekenkamer ter Auditie, 4544, fol. 8r.

47 NA, Rekenkamer ter Auditie, 4547. Compare Smit, Den Haag, pp. 206-7.

48 Compare the registers in NA, Rekenkamer ter Auditie, 4544, 4547. Jacob Muys, one of the rentmeesters of the annotated goods, was ordered to pay 10,926 pound to 'his excellency's kitchen' (Tracy, 'Emigré', p. 258).

49 Correspondentie Willem van Oranje, 2808.

50 NA, Rekenkamer ter Auditie, 4544. Casembroot had escaped from Flanders in 1572.
} 
accommodation problems in the rebel towns. The housing crisis even increased in the following years as the war generated new streams of refugees who sought asylum in urban safe havens. ${ }^{51}$ But a closer analysis reveals that the policies of the rebel authorities were not merely guided by the pressing refugee crisis. The practice of assignment suggests a consistent use of highly symbolical urban spaces that served to rehabilitate the victims of the former regime.

To understand the propaganda value of the housing transfer, it is important to consider the broader implications of the sentences of the Council of Troubles. Their orders for banishment had not just caused material damage, but also seriously undermined the honour and social status of those involved. From a legal point of view, banishment with the confiscation of goods could be regarded 'a civil death', as the law scholar Joos de Damhouder (1507-81) put it. ${ }^{52}$ The proclamations of the Council, which typically stated that those convicted were to be 'exiled forever and always', had in fact removed exiles from civic society. Indeed, Alva had given strict orders to 'take, break, and remove all signs of those sentenced and banished', which may be found in their former residences. ${ }^{53}$ The public memory of the outlaws had literally been erased. It is significant that Alva's instructions specifically concerned the public space as they referred to banners and signs that were visible from the outside, and did not mention any references to previous owners inside the buildings. The same notion of a purification of communal space could be distilled from his orders in 1568 to demolish the Brussels palace of the count of Culemborg, the place where the 'Compromise of nobles' had been founded two years earlier. Salt was later sprinkled over the open space and a pillar was erected, engraved with inscriptions in Spanish, Italian, French and Latin. Paradoxically, the text referred to the wish to 'obliterate the very memory of the conspiracies against the Roman Catholic Faith, the King's Majesty and against the provinces themselves, which oft have been hatched therein'. ${ }^{54}$

Alva's methods of purging the urban space of any reference to the exiles may have been modelled on several examples. There are some obvious parallels with practices in neighbouring France, where Protestant possessions were similarly confiscated and demolished during the wars of

\footnotetext{
51 Van Nierop, Het verraad, 195-201; Noordeloos, 'Fugitieve personen'.

52 Joos de Damhouder, Practycke ende handbouck in criminele zaecken (Leuven, 1555), p. 78.

53 Instructions from Alva, October 1569. Published in Verheyden, Les conseil, pp. 557-60. Similar versions in Marcus, Sententiën, pp. 432-4, 440.

54 The Fugger News-Letters: First Series, ed. Victor von Klarwill (New York, 1970), p. 10. I am grateful to Monica Stensland (Exeter College, Oxford) for this reference. For a strikingly similar phenomenon in Paris see Barbara Diefendorf, Beneath the Cross: Catholics and Huguenots in Sixteenth-Century Paris (New York, 1991) [hereafter Diefendorf, Beneath the Cross], pp. 83-4. The use of salt is noted in H. F. K. van Nierop, 'A Beggars' Banquet: The Compromise of the Nobility and the Politics of Inversion', European History Quarterly, xxi (1991) [hereafter Van Nierop, 'A Beggars' Banquet'], 429.
} 
religion. ${ }^{55}$ Historians have interpreted the seizure of Huguenot houses as a form of ritualized cleansing. Many French Catholics regarded their Protestant neighbours not just as heretics, but also as 'infected' elements that polluted their community. ${ }^{56}$ Alva's comparable policy of purgation had some local precedents as well. Corien Glaudemans has recently demonstrated how the removal of banished individuals in medieval Holland was generally reinforced by the simultaneous demolition of their residences. ${ }^{57}$ This radical method was later replaced by more symbolic forms of cleansing, comparable to the explicit removal of banners and signs of exiles by Alva. Finally, Marc Boone has shown how the Burgundian and Habsburg princes in the past had responded to urban revolts in the Low Countries by destroying possessions of rebels and by rearranging urban spaces. ${ }^{58}$

In the light of the strong connection between banishment and the symbolic cleansing of public space, it becomes understandable how the return of exiles triggered a reversal or a similar reshaping of urban spaces. The reintegration of those who had been considered 'dead' not so long before was a sensitive enterprise that required not only material compensation, but also a public rehabilitation of honour and status. The issue became all the more urgent because of the new political status of the former outlaws and their militant attitude: many exiles did not intend simply to reintegrate into the communities, which they had left several years earlier. Rather than trying to resume their previous positions in Holland society, the former outcasts were keen to appropriate a new political role, to establish a new religious order and to exploit their exclusive status as victims of Alva's 'tyranny'.

Against this background, the 'politics of annotation' reveals a systematic, sophisticated agenda. The connections between social rehabilitation and urban space become more apparent by revisiting the lists of appropriated Catholic houses. For example, it is telling that in Leiden the house of Claes Oem Jansz Buytewech - one of the town's wealthiest citizens and a known supporter of the Catholic wing - was temporarily granted to Pieter Cornelisz, the new Reformed minister of the town. ${ }^{59}$ On the prominent Breestraat, the residence of fugitive burgomaster Cornelis Claesz van der Hooge was occupied by Emden exile Jan van Hout, the re-established town secretary. ${ }^{60} \mathrm{~A}$ similar reversal of roles and related urban spaces

\footnotetext{
55 Examples in Philip Benedict, Rouen during the French Wars of Religion (Cambridge, 1981), pp. 114-45; Diefendorf, Beneath the Cross, pp. 73, 76-7, 84-90; Roberts, 'Huguenot Petitioning', pp. 62-77; The French Wars of Religion: Selected Documents, ed. David Potter (Basingstoke, 1997) [hereafter Potter, The French Wars], pp. 57, 83-4.

${ }_{56}$ See previous note, as well as Natalie Zemon Davis, 'The Rites of Violence', in Society and Culture in Early Modern France, ed. Natalie Z. Davis (Stanford, 1975), pp. 152-88.

${ }^{57}$ Glaudemans, Om die wrake wille, pp. 281-301. Also Iterson, Geschiedenis, p. 126.

${ }^{58}$ Marc Boone, 'Urban Space and Political Conflict in Late Medieval Flanders', Journal of Interdisciplinary History, xxxii (2002), 639.

59 NA, Rekenkamer ter Auditie, 4565, overview of annotated houses at Leiden, 1573.

${ }^{60}$ See previous note, as well as W. A. Fasel, 'De Leidse glippers', Jaarboekje voor de geschiedenis en oudheidkunde van Leiden en omstreken, xlviii (1956), 83.
} 
could be observed in Gouda in 1574. The house of burgomaster Jan Gerrit Hey, a staunch Catholic who had fled the town and had been involved in a loyalist counter-coup, was assigned to Albrecht van Egmond, former exile and recently appointed officer in the rebel army. ${ }^{61}$ The previous year he had been offered accommodation in Leiden, which was owned by loyalist Hendrick Gerritsz. ${ }^{62}$

The appropriation of such recognizable buildings by people who had previously been labelled as outcasts and criminals sent a powerful message to local Holland citizens. It must have appeared to them that the world had been turned upside down. The same message was also expressed in the relocation of commodities and the distribution of pensions. In September 1575 Nicolaas Mandekens received orders from William of Orange to deliver furniture for the house of returning exile Philip van der Aa. His commission explicitly noted that these commodities had to be taken from the houses of fugitive loyalists. ${ }^{63}$ In Gouda, the rentmeester responsible for 'annotated goods' was ordered to pay the newly arrived Calvinist minister. In addition, he had to grant the empty house of a Catholic priest to the widow of a man, who had been executed for religious heterodoxy a few years before. ${ }^{64}$ These victims of the former regime were now given ample chance to clear their debts at the expense of those who had been responsible for their exile and suffering. ${ }^{65}$

The seizure of Catholic properties by the Holland exiles explicitly mirrored Alva's earlier practices. This suggests that the transfer of possessions and housing in 1572 drew on distinct Habsburg traditions, which contemporaries will have recognized. By marking their arrival in this bold way, the repatriates presented the transition of the legitimate regime as a defining and irrevocable event. Their conscious 're-colouring' of urban spaces visualized both the breakdown of the old order and the re-establishment of their own place in society. Rebel troops, often commanded by former exiles, made similar use of the propaganda potential of loyalists' housing and urban space. The arrest and murder of the Catholic priest Cornelis Musius serves as a case in point. In December 1572 Musius was taken to Leiden on the instructions of Admiral Lumey, where he was subsequently tortured and brought to death. His executioners typically selected the empty residence of the renowned Catholic family Van Veen on the Pieterskerkhof to carry out their act of retribution. Musius' remains were then allegedly displayed at the 'blue stone', the marked space in front of the town hall where heretics had been executed

\footnotetext{
61 Van Eeghen, Dagboek, i. 1; Hibben, Gouda, pp. 80, 265.

62 NA, Rekenkamer ter Auditie, 4565, overview of annotated houses at Leiden, 1573. For Egmond's background see De Meij, De watergeuzen, pp. 18, 22-5, 28.

${ }^{63}$ Correspondentie Willem van Oranje, 2027. Mandekens also received orders to decorate the meeting room of the States of Holland with tapestries taken from the house of the 'loyalist' Countess of Aremberg. Smit, Den Haag, p. 293.

${ }^{64}$ She received the house by way of alimentation. Van Eeghen, Dagboek, i. xviii, 398; NA, Rekenkamer ter Auditie, 4571, annotated goods at Gouda, 1573-4.

65 Tracy, 'Emigré', p. 266.
} 
in previous years. ${ }^{66}$ The Amsterdam exiles, who managed to take power in their city in 1578 , behaved in a similar fashion. Following their coup, they transported the members of the loyalist Catholic faction to the Diemerdijk, a place just outside the jurisdiction of the city, where banished individuals had traditionally been left. ${ }^{67}$

The politics of inversion, which guided the exiles' strategy of reintegration and visualized the adoption of their new position in society, was not a new rhetorical model. In recent years, scholars have become more interested in the vocabulary, symbolic imagery and rituals that were at play in the Dutch revolt. ${ }^{68}$ Henk van Nierop has deciphered the 'Beggars' signs, which were employed by nobles in their opposition to the Habsburg government. They used the popular carnivalesque motive of 'turning the world upside down' to criticize the royal government and to formulate alternatives to political and religious arrangements. ${ }^{69}$ Historians have found it more difficult to map the reception of this mocking symbolism among citizens in the Low Countries. ${ }^{70}$ Unfortunately, there is a similar lack of material regarding the responses to the rituals employed by the returning exiles in the Holland towns in the 1570s. Nevertheless, despite the fact that their precise impact cannot be gauged, the repeated use of similar communicative models suggests that the urban population in the Low Countries was well acquainted with its rhetorical purpose. It is telling that a comparable phenomenon occurred in Flanders a few years later, where after the Pacification of 1576 cities such as Gent faced a parallel influx of returning Protestant exiles. In this changing climate, the residence of Lieven Snouck - a member of the Council of Troubles - was characteristically destroyed by a Gent mob. ${ }^{71}$

66 Petrus Opmeer, Martelaarsboek, ofte historie der Hollandse martelaren (Antwerp, 1700), pp. 134, 138-41; Ketters en papen onder Filips II, ed. S. Groenveld et al. (Utrecht, 1986), p. 178.

67 S. A C. Dudok van Heel, 'Waar waren de Amsterdamse katholieken in de zomer van 1585?', Jaarboek Amstelodamum, lxxvii (1985), 13.

68 Arnade, Van Nierop, 'The Political Culture', pp. 253-61; Alastair Duke, 'Dissident Propaganda and Political Organization at the Outbreak of the Revolt of the Netherlands', in Reformation, Revolt and Civil War in France and the Netherlands 1555-1585, ed. Philip Benedict et al. (Amsterdam, 1999) [hereafter Duke, 'Dissident Propaganda'], pp. 115-32; Daniel Horst, De Opstand in zwart-wit: Propagandaprenten uit de Nederlandse opstand 1566-1584 (Zutphen, 2003); Margit Thøfner, A Common Art: Urban Ceremonial in Antwerp and Brussels during and after the Dutch Revolt (Zwolle, 2007) [hereafter Thøfner, A Common Art].

69 Van Nierop, 'A Beggars' Banquet', 419-43; Edward Muir, Ritual in Early Modern Europe (Cambridge, 2005), pp. 97-106.

70 Peter Arnade, 'The Rage of the Canaille: The Logic of Fury in the Iconoclasm Riots of 1566', Emotions in the Heart of the City $\left(14^{\text {th }}-16^{\text {th }}\right.$ Century), ed. Elodie Lecuppre-Desjardin, Anne-Laure van Bruaene (Turnhout, 2005), pp. 93-114; Duke, 'Dissident Propaganda', p. 128; Thøfner, A Common Art, pp. 94-113. See also Monica Stensland, 'Not as Bad as All That: The Strategies and Effectiveness of Loyalist Propaganda in the Early Years of Alexander Farnese's Governorship', Dutch Crossing, xxxi (2007), 91-112.

71 A. Viaene, 'Vlaamse vluchtelingen te Douai: Hun verweer tegen Marnix' Biënkorf, 1578-1584', Handelingen van het genootschap voor geschiedenis gesticht onder de benaming Société d'émulation te Brugge, xciii (1956) 25. Other examples from Gent can be found in Marc Boone, 'The Dutch Revolt and the Medieval Tradition of Urban Dissent', Journal of Early Modern History, xi (2007) [hereafter Boone, 'The Dutch Revolt'], 368. 


\section{V}

Although the inverted use of houses and urban space that coincided with the return of exiles in the Holland towns may have been part of an established media strategy, it was by no means certain that their statements would be long-lasting. Indeed, the Pacification of Gent of 1576 sought to reconcile the opposing parties and explicitly ordered the restitution of possessions on both sides. The first article of the treatise stated that all parties would 'forgive, forget and hold things as if they had never happened'. ${ }^{72}$

The agreements of the Pacification were intended to serve the interests of refugees in both camps, and in the following months Protestant exiles indeed started to claim their former properties in the other provinces, notably Flanders and Brabant. ${ }^{73}$ Yet it soon became clear that many Holland towns set specific conditions which frustrated a parallel re-entry of Catholic loyalists. Catholic refugees were only allowed to return if they pleaded their allegiance to Orange and the States and swore an oath which forbade the public practice of any religion other than the Reformed. In some towns Catholics who had been involved in loyalist counter-coups in previous years were even formally excluded from re-entry. ${ }^{74}$ In the following years attempts at reconciliation were further subverted by increasing polarization in the Low Countries. Although many Catholics from Holland eventually returned and received their properties back, they lost their churches and former political offices forever.

In the meantime, their triumphant Protestant counterparts were unwilling to give up their recently acquired status in Holland and were keen to exploit a heroic self-image. Quite how effective this campaign was became clear in the following decades, when songs and poems were written, in which the 'aristocracy of exile' was cultivated and the tale of flight, exile and return was remodelled into a form of Protestant martyrdom, comparable to biblical precedents. ${ }^{75}$ This framing of events would have a profound impact on subsequent historical accounts and on the collective image of the revolt. In the nascent Dutch Republic, the experience of

\footnotetext{
${ }^{72}$ Edition taken from http://dutchrevolt.leidenuniv.nl, ed. Anton van der Lem. The Pacification also proclaimed that 'all pillars, trophies, inscriptions and other signs', which had been erected by Alva, had to be demolished. The same ideal of an extinguishment of memories to discord was expressed in the Edict of Amboise of 1563. Compare Potter, The French Wars, pp. 82-4.

${ }_{73}$ Spicer, French-speaking Reformed Community, p. 152; Guido Marnef, 'The Dynamics of Reformed Religious Militancy: The Netherlands, 1566-85', in Reformation, Revolt and Civil War in France and the Netherlands 1555-1585, ed. Philip Benedict et al. (Amsterdam, 1999), pp. 64-7.

${ }^{74}$ NA, Archief Cousebant, 1092, oath to be sworn by loyalist Catholics, 1576. Also Hibben, Gouda, p. 92; Smit, Den Haag, p. 297.

${ }^{75}$ R. B. Evenhuis, Ook dat was Amsterdam: De kerk der hervorming in de gouden eeuw (2 vols., Amsterdam, 1965), i. 86-7; J. C. Breen, 'Stichtelijke liederen van Laurens Jacobszoon Reael', Archief voor Nederlandsche Kerkgeschiedenis vi (1897), 355-82; H. A. Enno van Gelder, De levensbeschouwing van Cornelis Pietersz Hooft. Burgemeester van Amsterdam, 1547-1626 (reprint, Utrecht, 1982), pp. 4-6.
} 
Protestant exile thus developed into a distinctive mark of esteem, a badge of lasting exclusivity and newly invented patriotic pride. ${ }^{76}$

\section{VI}

Although scholars have devoted some attention to the cleansing of churches by Protestants and Catholics in the Dutch revolt, parallel re-arrangements of secular goods and spaces have remained largely unnoticed. This article has shown how such interventions in the urban space played a distinctive role in the civil war. Returning exiles exploited the symbolic potential of the houses and possessions of Catholic fugitives to mark their re-entry in the Holland towns. Two aims can be distinguished. First, the transfer and (temporary) appropriation of Catholic and loyalist possessions served as a form of material compensation for the confiscation of exile properties by the Council of Troubles. Secondly, the relocation of recognizable loyalist properties provided the returnees with a powerful tool to forge their rehabilitation in society and to reestablish their sense of honour and respectability. This strategy demonstrates how the returning exiles did not intend simply to reintegrate into local communities, but sought to style themselves as a natural new elite through the politics of annotation. These actions were partly based on established Habsburg traditions, which were imitated as well as reversed by them. Thus, past precedents offered the exiles models of proper action and the pathways to ensure the legitimacy of their return. ${ }^{77}$ However unique the tale of their reintegration and prominence in the nascent Dutch Republic may have been, it was the vocabulary of tradition that enabled the Protestant exiles to transform themselves from outlaws into icons of a new regime.

\footnotetext{
76 This Protestant image-building has not yet received full study. But see Simon Schama, The Embarrassment of Riches: An Interpretation of Dutch Culture in the Golden Age (1988), pp. 96-116; John Exalto, Gereformeerde heiligen: De religieuze exempeltraditie in vroegmodern Nederland (Nijmegen, 2005), pp. 233-5.

77 Boone, 'The Dutch Revolt', 351-75.
} 